\title{
Artificial neural network based technique for energy management prediction
}

\author{
N. Ab. Wahab ${ }^{1}$, Z. Mat Yasin ${ }^{2}$, N. A. Salim ${ }^{3}$, N. F. A. Aziz ${ }^{4}$ \\ ${ }^{1,2,3}$ Faculty of Electrical Engineering, Universiti Teknologi MARA, Malaysia \\ ${ }^{4}$ Institute of Power Engineering, Electrical Power Department, College of Engineering, \\ Universiti Tenaga Nasional, Malaysia
}

\begin{tabular}{l}
\hline \hline Article Info \\
\hline Article history: \\
Received May 20, 2019 \\
Revised Jul 23, 2019 \\
Accepted Aug 6, 2019 \\
\hline Keywords: \\
Artifical neural network \\
Electricity cost \\
Energy consumption \\
Energy management \\
Energy prediction
\end{tabular}

Keywords:

Artifical neural network

Electricity cost

Energy management

Energy prediction

\begin{abstract}
The energy management of electrical machine is significant to ensure efficient power consumption. Mismanagement of energy consumption could give impact on low efficiency of energy consumption that leads to power wastage. This paper presents analysis of power consumption and electricity costing of the electrical machineries and equipment in High Voltage (HV) and Electrical Machine (EM) Laboratories at Faculty of Electrical Engineering (FKE), Universiti Teknologi MARA (UiTM) Shah Alam, Selangor, Malaysia. The electrical data are collected using Fluke Meter 1750. Based on the analysis, it is found that the estimated annually electricity cost for HV Laboratory and EM Laboratory are RM 392.00 and RM 3197.76 respectively. For prediction of energy consumption of the two laboratories, Artificial Neural Network (ANN) algorithm is applied as computational tool using feedforward network type. The results show that the ANN is successfully modelled to predict the energy consumption.
\end{abstract}

\section{Corresponding Author:}

Norfishah Ab Wahab,

Faculty of Electrical Engineering, 40450 Shah Alam, Selangor, Malaysia.

Email: fishahahu@gmail.com

\section{INTRODUCTION}

Commercial building is known as high consumption electrical energy due to large capacity of electrical equipment and resources [1-3]. Hence, energy management is crucial to ensure high efficiency of power consumption [2]. In Malaysia, based on the Efficient Management of Electrical Energy Regulations 2008 that was introduced on 15 December 2008, the management of large commercial and industrial electrical consumer are required to develop and carry out the energy efficient measures in order to improve the utilization and efficiency of electrical energy in this organization [3]. Besides this, power planning is crucial for cost efficiency of power generation of an area; in which power forecasting plays essential part of energy management.

Numerous research in energy management had been performed. Part of energy management, that is energy audit were performed at public and commercial buldings. The results and recommendation from the audit could improve the energy efficiency. This led to increase of production efficiency, improve product quality and reduce the production cost [4-8]. Studies in energy management for the industries delt with heavy machineries were also conducted. It was found that with right size of space to placed heavy machineries and resources among the important parameters contribute to the energy consumption. Change in usage patterns and occupant awareness could also affected the amount of energy of the premise. These led to huge opportunities towards energy saving and improved energy efficiency [5-8]. 
For old rewound/faulty motors machineries that consumed high power can be changed to the new one that equipped with energy efficient system [7-8]. A study in energy management for steel rolling plant had been conducted by replacing the induction motor with more energy efficient and rescheduling the loads. It had proven that the electricity bills were reduced which results to reducing of unnecessary power loss [9-12]. Energy conservation had been conducted to carried out the potentials of energy saving with implementation of separate metering, reduction in electricity using on peak hours and use demand controller [13-15]. It helps reduce the unneeded load and estimate out the production cost [10], [16-17]. By introducing right technique in saving electricity and implement power factor correction could also contribute to the oppurtinities of energy saving [18].

The introduction of ANN to model and predict energy consumption have been widely proposed. Investigations in estimation of the electricity consumption through Artificial Neural Network (ANN) method had been performed. The estimation and prediction were succesfully implemented to predict electricity usage for daily and hourly consumption and also load forecasting [19]. Various ANN techniques were proposed and comparison were made to distinguish the best method. Amoongst the popular techniqes, is Learning levenberg-marquardt algorithm, was proposed as training algorithm. In this algorithm, the transfer function been used was tansig for hidden layer and purelin for output neurons.

ANN method also able to modeling energy consumption for random day and the next hours by using Boolean metering system [20-21]. The application of ANN has some advantages such as the following: the mapping function in neural network is very flexible and neural network have the ability of generalizing form a limit set of data points and giving a good result at new data points [22-23]. Feed forwardback propagation (FFBP) and the general regression neural network (GRNN) have been affirmed as two effective methods inmodelling and prediction by previous researchers. These two models are employed for the prediction of PV output power and had shown their effectiveness compared to statistical and autoregression approaches [24-26].

Based on the findings from the previous work, an investigation is performed to investigate the energy consumption at the Faculty of Electrical Engineering (FKE), UiTM Shah Alam, Selangor, Malaysia. The High Voltage (HV) and Electrical Machine (EM) Laboratories are chosen due to the fact that these two laboratories placed heavy machineries and equipment. The laboratories are used for undergradue students in running their experiments such as DC Machine, resistor load bank, inductor load bank and vacuum pump. Electrical data are collected using Fluke Meter 1750 and analysis are performed to determine the amount of energy consumed by the machineries. For prediction of energy consumption at both laboratories, Artificial Neural Network (ANN) using feedforward neural network type is applied. The prediction is usefull and can be further applied to other premised within the faculty for energy management.

\section{RESEARCH METHOD}

For the purpose of the project, two laboratories located at FKE, UiTM Shah Alam, Selangor are chosen, which are HV Laboratory (Block $4,4^{\text {th }}$ floor) and EM Laboratory (Block $4,6^{\text {th }}$ floor). The two laboratories are normally used for educational and experiment for the undergraduate engineering students. The HV Laboratory has two types of experiments and are performed on Monday and Friday weekly. While for the EM Laboratory, four different types of experiment are run from Tuesday until Friday weekly. Fluke Meter Power Quality Analyzer 1750. 1750 is used to collect the energy consumption for both laboratories. The data collected for both laboratories were taken from 18/10/2018 until 25/10/2018 during semester September 2018 - January 2019 session within one-week. All calculations are based on Tenaga Nasional Berhad (TNB) Tariff for commercial building; which is tariff C2 with current rates given RM0.365/kWh.

Artificial Neural Network (ANN) is developed for prediction of energy consumption. Using feedforward neural network type, the prediction is based on TRAINLM as training function, LEARNGDM as learning function, MSE as performance function and LOGSIG as transfer function. The input data are power consumption, number of experiment run, hours of experiment and electricity cost while the output data is energy consumption. For the development of the ANN, the input data are divided into $70 / 30$ in terms of percentage of training and testing. The 70/30 ratio is to give the higher coefficient of correlation. The flowchart of the ANN development for the testing and traing are as shown in Figure 1(a) and 1(b) respectively. 


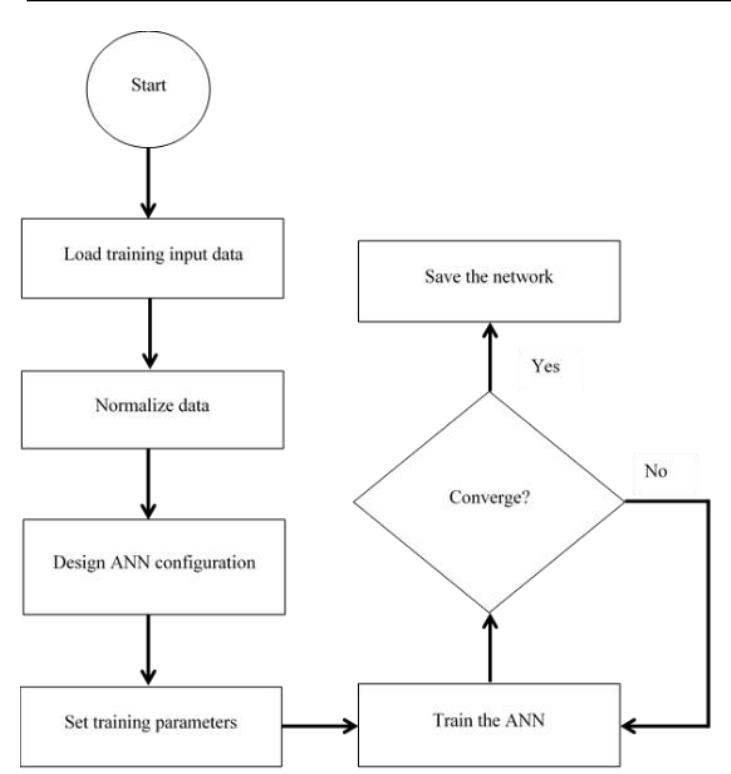

(a)

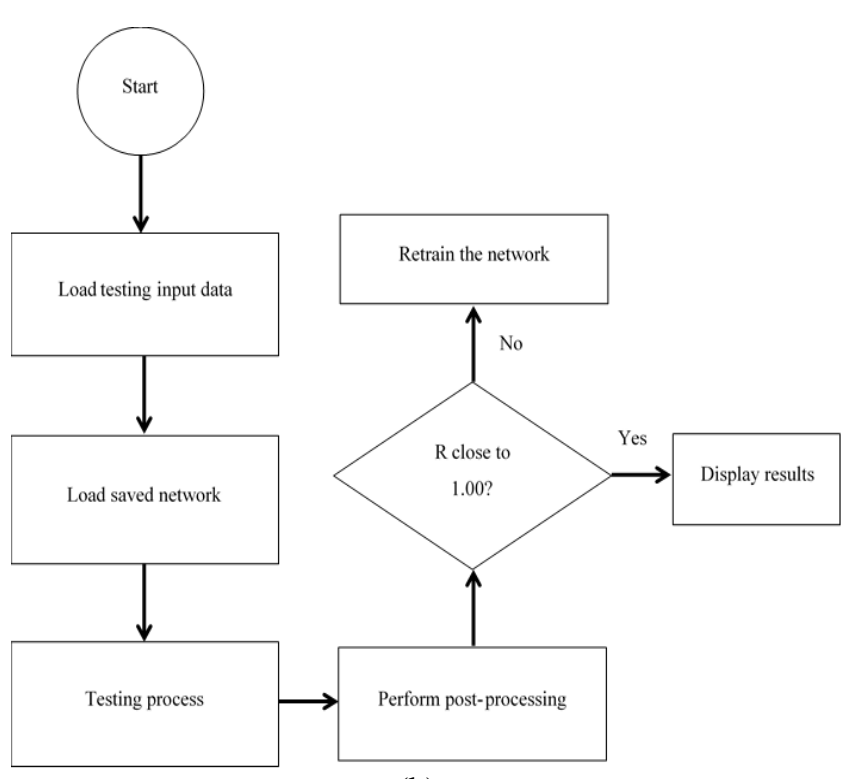

(b)

Figure 1. ANN Development (a) ANN Testing and, (b) Training workflow

\section{RESULTS AND ANALYSIS}

\subsection{Energy Consumption}

Table 1 shows the energy consumption for HV Laboratory taken from 18/10/2018 until 25/10/2018 in semester September 2018 - January 2019 session. It is found that the higher energy usage for HV Laboratory is $18.9 \mathrm{kWh}$ on Friday. Based on the weekly data, prediction of energy consumption for monthly and annually are calculated. It is found that the total energy consumption for one week is $30.24 \mathrm{kWh}$, and monthly is $120.96 \mathrm{kWh}$. The monthly energy consumption is multiplied by four weeks since the same experiment with same equipment are conducted throughout the semester in every week. Based on this, total annually of energy consumption is predicted at $967.68 \mathrm{kWh}$. The total annually times by eight months because in one year there are two semesters which is September-January and July- Mac.

Table 1. Energy Consumption of HV Laboratory

\begin{tabular}{|c|c|}
\hline & TOTAL ENERGY CONSUMPTION (kWh) \\
\hline Data Collected & $11.34 \mathrm{kWh}$ \\
\hline (Daily Basis) & $18.90 \mathrm{kWh}$ \\
\hline & Total weekly $=$ Sum of daily \\
\hline & Total weekly $=11.34 \mathrm{kWh}+18.90 \mathrm{kWh}$ \\
\hline Weekly(Calculated) & Total weekly $=30.24 \mathrm{kWh}$ \\
\hline & Total monthly = sum of weekly x 4 weeks \\
\hline Monthly( Predicted) & Total monthly $=120.96 \mathrm{kWh}$ \\
\hline Annually(Predicted) & $\begin{array}{l}\text { Total annually }=\text { sum of weekly } \times 8 \text { months } \\
\text { Total annually }=120.96 \mathrm{kWh} \times 8 \text { months }\end{array}$ \\
\hline $\begin{array}{l}\text { Semester: (Sept } 2018 \text { - Jan 2019) and (Mac } \\
2019 \text { - July 2019). }\end{array}$ & Total annually $=967.68 \mathrm{kWh}$ \\
\hline
\end{tabular}

Table 2 represents the calculation of EM Laboratory taken from 21/09/2018 until 28/09/2018 in semester September 2018 - January 2019 session. The higher energy consumption is $87.00 \mathrm{kWh}$ which is on Tuesday whereby the experiment conducted using DC Generator and Balance Three Phase Circuit. Based on the observation, the DC Generator experiment consumed more energy consumption compared to Balance Three Phase Circuit experiment. This is because the equipment used to run DC Generator needs more power to operate the machine. Based on weekly data, prediction of energy consumption on monthly and annually are calculated. It is found that the total energy consumption for one week is $273.78 \mathrm{kWh}$ and in monthly the EM experiments consumed $1095.12 \mathrm{kWh}$. The monthly energy consumption times four week because same experiment with same equipment are conducted weekly. The total annually of energy consumption is 8760.96 
$\mathrm{kWh}$. The total annually is multiplied with eight months because in one year there are two semesters which is September-January and July-March.

Table 2. Energy Consumption of EM Laboratory

\begin{tabular}{|c|c|}
\hline & TOTAL ENERGY CONSUMPTION (kWh) \\
\hline Tuesday & $87.00 \mathrm{kWh}$ \\
\hline Data Collected & $68.04 \mathrm{kWh}$ \\
\hline (Daily Basis) & $63.66 \mathrm{kWh}$ \\
\hline Friday & $55.08 \mathrm{kWh}$ \\
\hline Weekly(Predicted) & $\begin{array}{c}\text { Total weekly }=\text { sum of daily } \\
\text { Total weekly }=87.00 \mathrm{kWh}+68.04 \mathrm{kWh}+63.66 \mathrm{kWh}+55.08 \mathrm{kWh} \\
\text { Total weekly }=273.78 \mathrm{kWh}\end{array}$ \\
\hline Monthly(Predicted) & $\begin{array}{c}\text { Total monthly }=\text { sum of weekly } \mathrm{x} 4 \text { weeks } \\
\text { Total monthly }=273.8 \mathrm{kWh} \\
\text { x } 4 \text { weeks }\end{array}$ \\
\hline Annually(Predicted) & $\begin{array}{l}\text { Total monthly }=1095.12 \mathrm{kWh} \\
\text { Total annually }=\text { sum of monthly } \times 8 \text { months }\end{array}$ \\
\hline \multirow[t]{2}{*}{$\begin{array}{l}\text { Semester: (Sept } 2018 \text { - Jan 2019) and (Mac } 2019 \text { - July } \\
\text { 2019) }\end{array}$} & $\begin{array}{l}\text { Total annually }=1095.2 \\
\text { x } 8 \text { months }\end{array}$ \\
\hline & Total annually $=8760.96 \mathrm{~kW}$ \\
\hline
\end{tabular}

Table 3. Total Energy Consumption for Two Laboratories

\begin{tabular}{ll}
\hline & TOTAL ENERGY CONSUMPTION $(\mathrm{kWh})$ \\
\hline Weekly(Calculated) & $30.24 \mathrm{kWh}+273.78 \mathrm{kWh}=304.02 \mathrm{kWh}$ \\
Monthly(Predicted) & $120.96 \mathrm{kWh}+1095.12 \mathrm{kWh}=1216.08 \mathrm{kWh}$ \\
Annually(Predicted) & $967.68 \mathrm{kWh}+8760.9 \mathrm{kWh}=9728.58 \mathrm{kWh}$ \\
\hline
\end{tabular}

Based on Table 3, the energy consumption for both laboratories in weekly is calculated and the value is $304.02 \mathrm{kWh}$. The total energy consumption for monthly for both laboratories is $1216.08 \mathrm{kWh}$ while for annually is $9728.58 \mathrm{kWh}$. Based on these analysis, total weekly consumption of EM Laboratory consumes more energy consumption than HV Laboratory because EM Laboratory run four experiments in a week while HV Laboratory runs two experiments only.

\subsection{Electricity Cost}

The calculation for electricity costing is performed by using Tenaga Nasional Berhad (TNB) tariff. The tariff category is tariff $\mathrm{C} 2$ which is for medium voltage peak/off peak commercial tariff (all $\mathrm{kWh}$ during peak period), with current rates $36.5 \mathrm{sen} / \mathrm{kWh}$.

a) High Voltage Laboratory

Table 4 shows the the electricity cost for HV Laboratory on Monday and Friday that consumed high energy when running the experiments. The calculated and predicted electricity cost are tabulated in Table 5. The electricity cost for one week is calculated at RM 11.04. The predicted amount is RM 44.16 pr month and RM 353.28 per annual. The electricity cost is low because it only measures on machine load, excluding the air conditioner, lighting and other loads. Moreover, the machine had been installed in single phase condition and only at red phase.

Table 4. Electricity Cost for HV Laboratory

\begin{tabular}{cccc}
\hline DAY & DATE & ENERGY CONSUMPTION $(\mathrm{kWh})$ & ELECTRICITY COST $(\mathrm{RM})$ \\
\hline Friday & $19 / 10 / 2018$ & 18.90 & $18.90 \mathrm{kWh} \times$ RM $0.365=$ RM 6.90 \\
Monday & $22 / 10 / 2018$ & 11.34 & $11.34 \mathrm{kWh}$ x RM 0.365= RM 4.14 \\
\hline
\end{tabular}

Table 5. Total Electricity Cost for HV Laboratory Based on Weekly, Monthly and Annually

\begin{tabular}{ll} 
TOTAL ELECTRICITY COST (RM) \\
\hline Weekly(Calculated) & $=$ Sum of daily \\
& $=$ RM $6.90+$ RM 4.14 \\
& $=$ RM 11.04 \\
& $=$ Sum of weekly $\times 4$ weeks \\
& $=$ RM $11.04 \times 4$ weeks \\
& $=$ RM 44.16 \\
& $=$ Sum of monthly $\times 8$ months \\
& $=$ RM $44.16 \times 8$ months \\
& $=$ RM 353.28 \\
\hline
\end{tabular}


Table 6 shows the daily electricity cost for EM Laboratary. It is found that on Tuesday, the laboratory consumed the highest energy consumption that contributed to highest electricity cost. The total electricity cost for one week is RM 99.93.

Table 6. Electricity Cost for EM Laboratory

\begin{tabular}{cccc}
\hline DAY & DATE & ENERGY CONSUMPTION $(\mathrm{kWh})$ & ELECTRICITY COST $(\mathrm{RM})$ \\
\hline Tuesday & $25 / 09 / 2018$ & 87.00 & $87.00 \mathrm{kWh} \times \mathrm{RM} 0.365=\mathrm{RM} 31.76$ \\
Wednesday & $26 / 09 / 2018$ & 68.04 & $68.04 \mathrm{kWh} \times \mathrm{RM} 0.365=\mathrm{RM} 24.83$ \\
Thursday & $27 / 09 / 2018$ & 63.66 & $63.66 \mathrm{kWh} \times \mathrm{RM} 0.365=$ RM 23.24 \\
Friday & $28 / 09 / 2018$ & 55.08 & $55.08 \mathrm{kWh} \times \mathrm{RM} 0.365=$ RM 20.10 \\
\hline
\end{tabular}

Table 7 tabulated the predicted monthly and annually electricity cost; which are RM 399.72 and RM 3197.76 respectively. It is found that, the electricity cost for EM Laboratory is higher compared to HV Laboratory because the number of experiments runs are four times per week in EM Laboratory, compared to HV Laboratory that runs only two times per week. Besides that, there are more machineries and equipment in the EM compared to HV laboratory.

Table 7. Total Electricity Cost for EM Laboratory Based on Weekly, Monthly and Annually

\begin{tabular}{ll}
\hline & \multicolumn{1}{c}{ Total Electricity Cost (Rm)) } \\
\hline Weekly(Calculated) & Sum of daily= RM 31.76 + RM 24.83 + RM 23.24 + RM 20.10= RM 99.93 \\
Monthly(Predicted) & Sum of weekly x 4 months= RM 99.93 x 4 months= RM 399.72 \\
Annually(Predicted) & Sum of monthly x 8 months= RM 399.72 x 8 months= RM 3197.76 \\
\hline
\end{tabular}

\subsection{Total Electricity Cost for Two Laboratories}

Table 8 summarized the total amount of calculated and predicted electricity cost for both laboratories. The total calculated weekly electricity cost for both laboratories is RM 110.97. While the predicted electricity costs is RM 443.88 per month, that amounted to RM 3551.04 anually.

Table 8. Total Electricity Cost for Two Laboratories

\begin{tabular}{ll}
\hline & \multicolumn{1}{c}{ Total Electricity Cost (RM) } \\
\hline Weekly(Calculated) & RM 11.04 + RM 99.93 = RM 110.97 \\
Monthly(Predicted) & RM 44.16 + RM 399.72= RM 443.88 \\
Annually(Predicted) & RM 353.28 + RM 3197.76 = RM 3551.04 \\
\hline
\end{tabular}

\subsubsection{Prediction of Energy Consumption using Artificial Neural Network (ANN) Method}

Finally, the prediction of the energy consumption for both laboratories is modelled using ANN algorithm. Refer to Figure 2(a), the prediction energy consumption on HV Laboratory shows value of correlation of training is found at $\mathrm{R}=0.99984$ while testing is $\mathrm{R}=0.99913$. MSE found in training set is 9.8837e-06 at epoch 19. In Figure. 1(b), the prediction for EM Laboratory obtained value of correlation of training is $\mathrm{R}=0.99994$ and testing is $\mathrm{R}=0.99977$. MSE for training set found by algorithm is $9.8939 \mathrm{e}-06$ at epoch 29. Training performance for both laboratories are found converged. Therefore, the predictions of energy consumption for both laboratories are successfully achieved. Finally, this ANN method prediction can be applied by the Faculty of Electrical Engineering, UiTM Shah Alam in forecasting future energy consumption. 


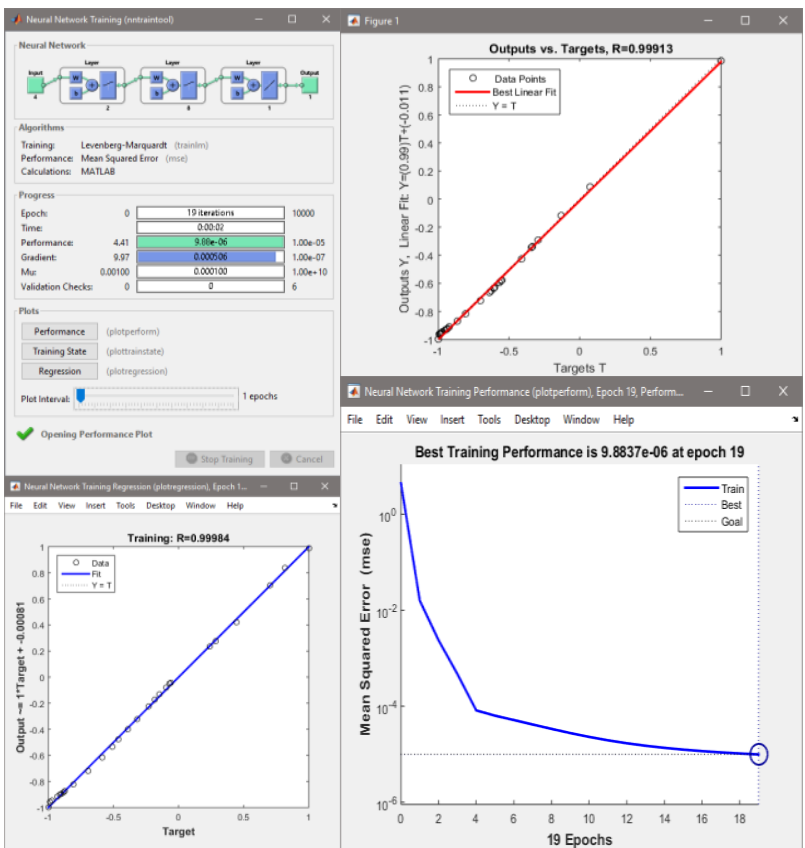

(a)

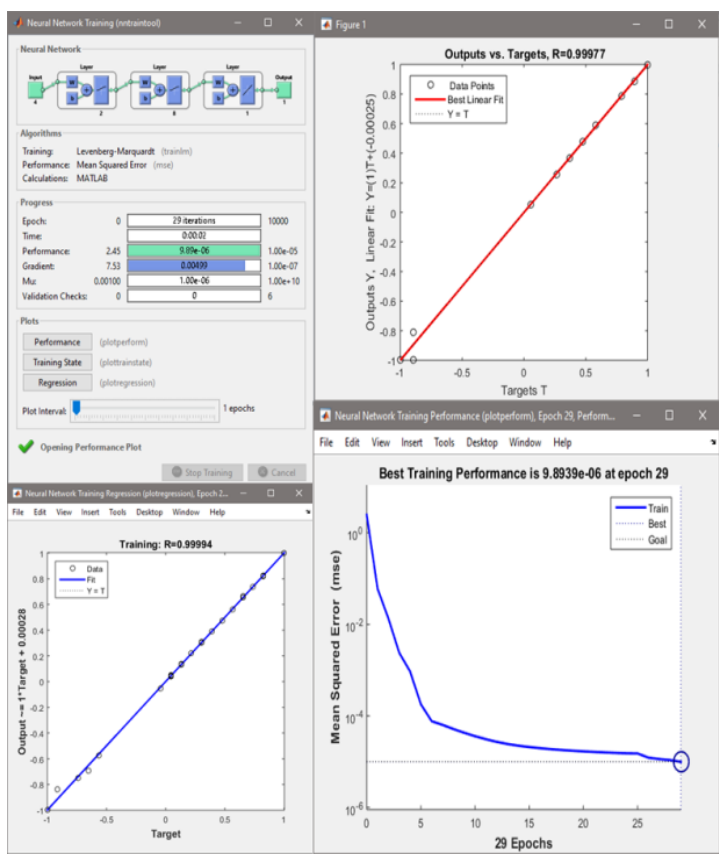

(b)

Figure 2. ANN prediction for (a) HV Laboratory, (b) EM Laboratory

\section{CONCLUSION}

The energy consumption and electricity costing for HV and EM Laboratories were successfully analyzed and presented. From this analysis, it was found that the total energy consumption of HV Laboratory is lower than EM Laboratory. The electricity cost for HV Laboratory was RM 392.00 per year while EM Laboratory RM 3197.76. For prediction of energy consumption, ANN was successfully simulated and tested. The ANN shows the best result prediction of energy consumption with $\mathrm{R}=0.99913$ for HV Laboratory while EM Laboratory $\mathrm{R}=0.99977$ with training results for both laboratories were found converged.

\section{ACKNOWLEDGEMENT}

The authors would like to acknowledge The Institute of Quality and Knowledge Advancement (InQKA), Universiti Teknologi MARA (UiTM), Shah Alam, Selangor, Malaysia for the financial support of this manuscript.

\section{REFERENCES}

[1] S. Zadey, S. Chafle, and A. S. Lilhahre, "Analysis of Various Parameters by Energy Audit," Int. Conf. Commun. Signal Process., pp. 1560-1564, 2016.

[2] N. S. Lopez, J. Gonzaga, and L. A. G. Lim, "Energy Audit and Analysis of the Electricity Consumption of an Educational Building in the Philippines for Smart Consumption," IEEE 9th International Conference on Humanoid, Nanotechnology, Information Technology, Communication and Control, Environment, and Management (HNICEM) 2017.

[3] SEDA Malaysia, Electrical Energy Audit Guidelines. 2016, Sustainable Energy Development Authority (SËDA) Malaysia, Copyright $\odot$ Seda Malaysia 2019.

[4] Pai M. A., "Energy Function Analysis for Power System Stability," Dordrecht, Kluwer Academic Publishers, 1989.

[5] B. Duggal and D. P. Singh, "Energy Audit of Individual Air Conditioners: A case study," India Int. Conf. Power Electron. IICPE, vol. 2016-Novem, 2017.

[6] S. K. Rajput and O. Singh, "Energy Audit in Textile Industry: A Study with Ring Frame Motor," ICCCCM 2016 2nd IEEE Int. Conf. Control Comput. Commun. Mater., no. Iccccm, pp. 2-5, 2017.

[7] G. S. Grewal, B. S. Rajpurohit, and J. G. Singh, "Energy Management in Steel Rolling Plant," Int. Conf. Util. Exhib. 2014 Green Energy Sustain. Dev. (ICUE 2014), no. March, pp. 1-7, 2014.

[8] A. Arya, Jyoti, P. Arunachalam, N. Bhuvaneswari, A. Kumar, L. Ramesh, V. Ganesan, and H. Egbert, "Review on Industrial Audit and Energy Saving Recommendation in Aluminium Industry," 2016 Int. Conf. Control Instrum. Commun. Comput. Technol. ICCICCT 2016, pp. 758-764, 2017. 
[9] Krishna Prakash N; Prasanna Vadana D, "Machine Learning Based Residential Energy Management System," 2017 IEEE International Conference on Computational Intelligence and Computing Research (ICCIC)

[10] Rodrigo F. Berriel; André Teixeira Lopes; Alexandre Rodrigues; Flávio Miguel Varejão, Thiago Oliveira-Santos, "Monthly energy consumption forecast: A deep learning approach,"2017 IEEE International Joint Conference on Neural Networks (IJCNN), 2017.

[11] I. Madanhire and C. Mbohwa, "Energy Management Options in a Fertilizer Manufacturing Plant," 2015 Int. Conf. Ind. Eng. Oper. Manag., pp. 1-11, 2015.

[12] I. Sato and A. Shinohara, "Visualization and Analysis of Electrical Energy Consumption in Laboratories," International Congress on Advanced Applied Informatics (IIAI-AAI), pp. 3-6, 2016.

[13] A. E. Tümer, S. Koçer, and A. Koca, "Estimation of the Electricity Consumption of Turkey Through Artificial Neural Networks," ScienceDirect, pp. 315-318, 2016.

[14] Najihah Zakaria, S. N. Azemi, P. J. Soh, C.B.M. Rashidi, A Abdullah Al-Hadi, "FSS on energy saving glass for rf communication enhancement in modern building," Indonesian Journal of Electrical Engineering and Computer Science, Vol. 14, No. 2, May 2019, pp. 537 545.

[15] N. Tanasi, G. Jankes, M. Stameni, A. Nikoli, M. Trnini, and T. Simonovi, "Potentials for Reducing Primary Energy Consumption Through Energy Audit in the Packaging Paper Factory," 3rd Int. Symp. Environ. Friendly Energies Appl. EFEA 2014, pp. 2-6, 2014.

[16] Noor Ameera Zakaria, Mohammad Yusri Hassan, Hayati Abdullah, Md Pauzi Abdullah, Faridah Hussin, Siti Maherah Hussin, Nur Najihah Abu Bakar, "Energy efficiency index by considering number of occupants: a study on the lecture rooms in a university building," Indonesian Journal of Electrical Engineering and Computer Science," Vol. 15, No. 3, September 2019, pp. 1154 1160.

[17] F. Rodrigues, C. Cardeira, and J. M. F. Calado, "The Daily and Hourly Energy Consumption and Load Forecasting Using Artificial Neural Network Method: A Case Study Using a Set of 93 Households in Portugal," Energy Procedia, vol. 62, pp. 220-229, 2014.

[18] W. Chen and S. Varadarajan, "Integration of design of experiments and artificial neural networks for achieving affordable concurrent design," in Proceedings of the 38th AIAA/ASME/ ASCE/AHS/ASC Structures, Structural Dynamics, and Materials Conference and AIAA/ASME/AHS Adaptive Structures Forum, pp. 1316-1324, April 1997.

[19] Ahmad Fateh Mohamad Nor, Marizan Sulaiman, "Voltage instability analysis based on modal analysis technique and artificial neural network," Indonesian Journal of Electrical Engineering and Computer Science, Vol. 13, No. 3, March 2019, pp. 1274 1279.

[20] S. Karupiah, M.H. Hussain, I. Musirin, S.R.A. Rahim, "Prediction of overcurrent relay miscoordination time using urtificial neural network," Indonesian Journal of Electrical Engineering and Computer Science, Vol. 14, No. 1, April 2019, pp. 319 326.

[21] A. F. M. Nor, "Study of Voltage and Power Stability Margins of Electrical Power System Using ANN," IET Conference Publications. Kuala Lumpur, pp. 1-7, 2016.

[22] Aminmohammad Saberian, H. Hizam, M. A. M. Radzi, M. Z. A. Ab Kadir, and Maryam Mirzaei, "Modelling and Prediction of Photovoltaic Power Output Using Artificial Neural Networks," International Journal of Photoenergy, Vol. 2014, Article ID 469701.

[23] A. Mellit and S. Shaari, "Recurrent neural network-based forecasting of the daily electricity generation of a Photovoltaic power system," in Ecological Vehicle and Renewable Energy (EVER), pp. 26-29, Monte-Carlo, Monaco, March 2009.

[24] Goh H. H., et al., "Evaluation for Voltage Stability Indices in Power System Using Artificial Neural Network," Procedia Engineering. Elsevier B.V., pp. 1127-36, 2015.

[25] O. Emmanuel, M.L. Othman, H. Hizam, M.M. Othman, "Artificial Neural Network Application in Optimal Coordination of Directional Overcurrent Protective Relays in Electrical Mesh Distribution Network," Applied Mechanics and Materials. 2015. Vol. 785. 48-52.

[26] Zhou D. Q., "Online Monitoring of Voltage Stability Margin Using an Artificial Neural Network," IEEE Transactions on Power Systems, vol/isue: 25(3), pp, 1566-74, 2010.

\section{BIOGRAPHIES OF AUTHORS}

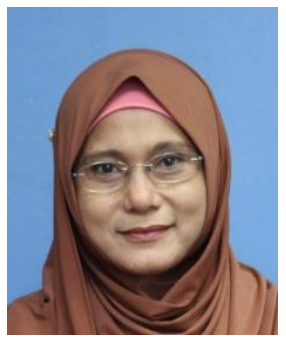

Norfishah Ab Wahab was born in Malaysia, in 1963. She received the degree in Electronics Engineering from Universiti Teknologi MARA (UiTM), Malaysia, MSc in Telecommunication and Information Engineering and obtained her $\mathrm{PhD}$ in microwaves and electromagnetism from the same university. Currently, she is a senior lecturer in Faculty of Electrical Engineering, UiTM Shah Alam, Malaysia. She has been working in UiTM since April 2008. From 1992 to 2004, she was employed by Telekom Malaysia. She worked in various divisions such as microwave, fiber cable and network system departments. Her major research areas are in microwave and Electromagnetic Modeling, Low-powered Energy Harvesting, Artificial Intelligence and Energy Management. 

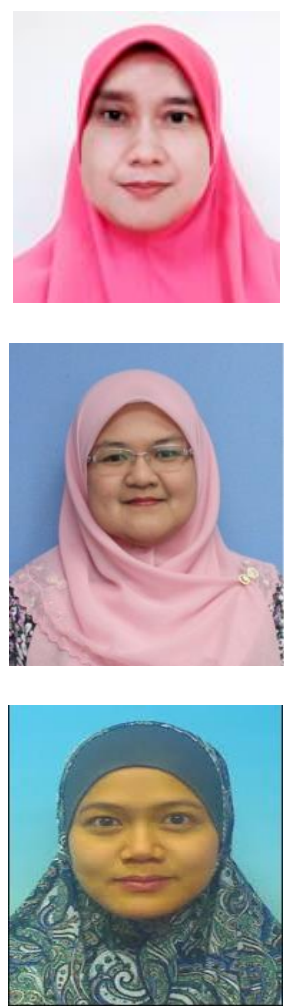

Zuhaila Mat Yasin graduated from Universiti Sains Malaysia with honours degree in Electrical and Electronics Engineering in 1998. She obtained her MSc degree in 2008 and PhD degree in 2015 from Universiti Teknologi MARA. She is currently a senior lecturer at Universiti Teknologi MARA, Malaysia. Her research interest includes power system operation, optimization, distributed generation, Artificial Intelligence and smart grid system.

Nur Ashida Salim received her Ph.D in Electrical Engineering from Universiti Teknologi MARA Malaysia in 2015 and MEng (Power System \& Electrical Energy) from Universiti Malaya in 2006. She is currently a lecturer at Universiti Teknologi MARA, Malaysia. Her research interests include power system reliability, power system planning, power system stability and power system risk assessment.

Nur Fadilah Ab Aziz received her Ph.D in Electrical Engineering from Universiti Teknologi MARA Malaysia in 2014 and M.Eng. (Hons.) in Electrical Engineering from University of Southampton, in 2006. She is currently a senior lecturer at Universiti Tenaga Nasional (UNITEN) Malaysia. Her research interests include power system planning, power system stability and Artificial Intelligent (AI) application in power system. 